\title{
OBITUARIES
}

For the full versions of articles in this section see bmj.com

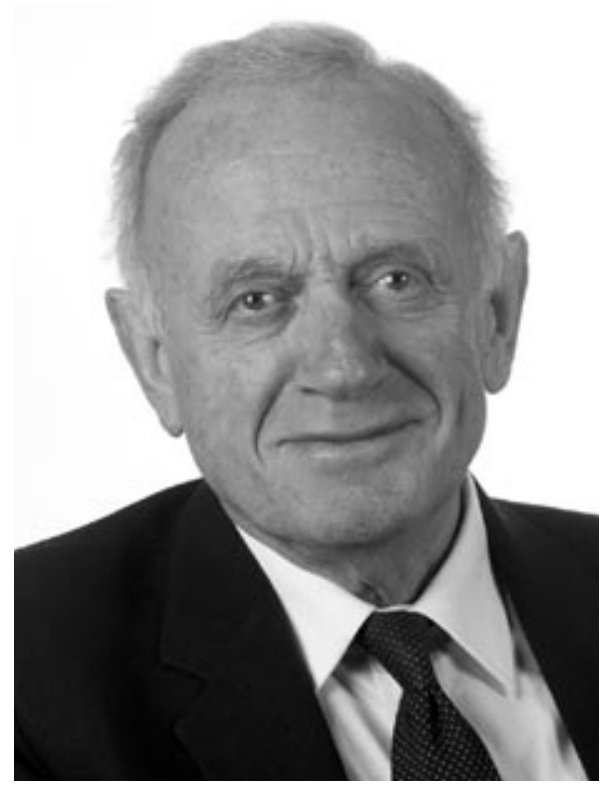

\section{Arthur Hamilton Crisp}

Psychiatrist who defined anorexia nervosa

We owe our understanding of anorexia nervosa to Arthur Crisp, who earned an international reputation for the meticulous research that enabled him to define its core feature: the fear and avoidance of normal body weight. $\mathrm{He}$ defined the factors that contribute to the disorder's development, and these have stood the test of time. His treatment programme was, in its day, considered the gold standard.

A mild, unpretentious, generous, and approachable man, he also carried out research (behavioural, psychodynamic, and epidemiological) into sleep disorders, psychological factors in heart attacks, migraine, obesity, and smoking. His humanistic approach was to define each patient's social, biological, and psychological features, and he used a range of pharmacological and psychological therapies. He developed psychiatric services around St George's Hospital in south west London, and incorporated Springfield, the local psychiatric unit, into the teaching hospital framework. He developed a wide range of specialised psychiatric services.

He edited the Journal of Medical Psychology and was visiting professor to Harvard and Sydney universities. He was a fellow of three royal colleges: psychiatrists (1971), physicians of London (1975), and physicians of Edinburgh (1972).

As London University's dean of medicine in the 1970 s he supervised medical education in 25 undergraduate and postgraduate teaching hospitals, five dental and two pharmacy schools, and a veterinary college. He chaired the advisory committee to the European Community during 1983-5. As chairman of the General Medical Council's education committee he broadened the curriculum to incorporate psychology and sociology. He was an active member of the Royal College of Psychiatrists, including chairing the college's committees set up to respond to the Ashworth inquiry and the Tomlinson report, which looked at neglect of patients in institutions and care standards. He advised the Chinese and Japanese governments, and was an adviser to the World Health Organization until shortly before his death.

Crisp was the son and grandson of an electrical engineer. He shared their devout Christianity. At Watford Grammar School he planned to study engineering at Imperial College, though his mother wanted him to join the civil service. He was captain of rugby and athletics and won a cap as a flanker for the 1948 English schools rugby team.

While waiting to join up for national service he suffered an appalling knee injury that hospitalised him for nine months and left him with a permanent left foot drop. Nevertheless, he completed his national service and-on 29 December 1950, when he was 20 and had just finished a medical consultationhe decided he wanted to be a doctor and possibly a missionary. He graduated in 1956 from King's College and Westminster Hospital, winning prizes in medicine, surgery, and social medicine. He did his house jobs at Westminster, and that same year he was invited to provide medical care for Hungarian refugees.

He trained in neurosurgery under Sir Wylie McKissock, best remembered as being keen on lobotomy at Atkinson Morley Hospital; he also started his psychiatry training there. He was then introduced to Sir Denis Hill, head of psychiatry at the Middlesex Hospital, where he worked as lecturer and then senior lecturer.

Hill became his mentor, and he turned down an opportunity to work at the Maudsley and Institute of Psychiatry. He shone on ward rounds and at clinical discussions he regularly astounded colleagues with his knowledge of the psychiatric literature. In 1969 he was appointed head of psychiatry (later mental health) at St George's. He remained there for the rest of his career.

He published 330 papers and four books: Nutrition and Mood (with Edward Stonehill) (1976), Anorexia-Let Me Be (1980), When Dieting Becomes Dangerous-A Guide to Understanding and Treating Anorexia and Bulimia (with Deborah Michel and Susan Willard) (2003), and Every Family in the Land: Understanding Prejudice and Discrimination Against People with Mental Illness (2003).

Crisp was a very private person who fought his corner without rancour. $\mathrm{He}$ often said his family was the greatest source of fulfilment in his life.

In 2001, in his retirement, he took on the task of director of the "Changing Minds Campaign" for the Royal College of Psychiatrists, looking at ways of dealing with the stigma that psychiatric patients suffer. His recreations were golf and wood carving, for which he won awards.

He died at home, of stomach cancer, and is buried at St Mary's Church in Friston, Suffolk, where he had a cottage. $\mathrm{He}$ is survived by his wife and three sons. Caroline Richmond

Arthur Hamilton Crisp, head of psychiatry (later mental health), 1967-95, and dean of medicine, 1976-80, London University (b 1930; q Westminster 1956; MD, DSc, FRCPsych, FRCP Ed, FRCP), died from stomach cancer on 13 October 2006. 


\section{Charles Maxwell Boucher}

Former senior medical officer, Northwest Division Regional Medical Service (b 1916; q Queen's University, Belfast, 1940; MD, MRCGP), died from primary tumour of the pons 7 January 2007.

After qualifying, Charles Maxwell Boucher volunteered for the Royal Army Medical Corps in Iraq. In 1944 he was wounded in Italy, and after a long spell in hospital and demobilisation, he succeeded to his father's practice in County Down. In 1956 he joined the regional medical service in Leeds and later London before serving as divisional medical officer of the northwest division in Manchester. After he retired he worked part time for the department in Devon. In his younger days he was a keen cricketer and on retirement a keen golfer. Predeceased by his wife, Peggy, in 1999, he leaves three children and seven grandchildren. Sue Redman

\section{George Hargreaves Dunstone}

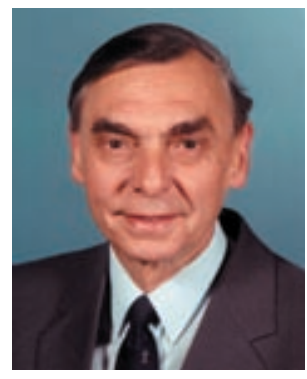

Former consultant surgeon Dryburn Hospital, Durham (b 1925; q Durham, 1948; FRCS), died from bronchopneumonia and essential thrombocythaemia on 15 November 2006.

After qualifying, George ("Steve") Hargreaves Dunstone served as medical officer with the Gurkha Rifles in Malaya from 1949 to 1951. During subsequent surgical training he developed an interest in oesophageal surgery. As consultant surgeon at Dryburn Hospital he forged strong links with Australia, and a succession of trainees came to Durham to take advantage of his expertise in vascular and oesophageal surgical techniques. He was postgraduate tutor and college tutor for the Royal College of Surgeons. An active member of the Vascular Surgical Society and Hadrian Surgical Club, he was president of the North of England Surgical Society, 1984-5. His interests included fly fishing, travel, and bowls. He leaves a wife, Mavis; two daughters; and two grandsons.

Antony Cook, David Wood

\section{Hugh Douglas Gemmell}

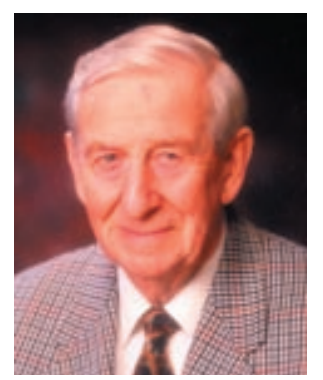

Former general practitioner and trainer Westbury, Shropshire (b 1919; q Glasgow 1945; MRCGP), d 6 January 2007.

Hugh Douglas Gemmell was proud of his Scottish ancestry and retained a deep love for the west coast. He was an accomplished chess player and was Scottish junior champion. He was on the local medical committee for many years and represented it at the annual conference, taking his turn as president of Shropshire and mid-Wales branch of the British Medical Association. Hugh was a keen shot, enthusiastic gardener, and talented golfer. He and his wife participated enthusiastically in village activities. He leaves a wife, Phoebe, and two sons.

John E Evans

\section{Henry Bushman Goodall}

Former reader in haematology University of Dundee (b 1921; q St Andrews 1944; MD, FRCPath), died from a myocardial infarction on 23 September 2006.

After house jobs, Henry Bushman Goodall served in the Royal Army Medical Corps, 1946-8, mainly in the Middle East, where he was

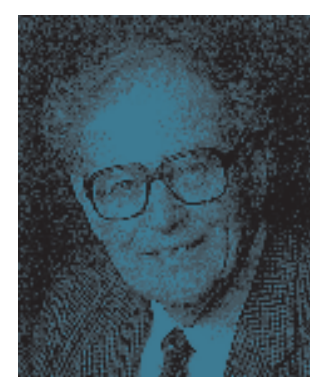

trained in tropical pathology. After demobilisation, he continued his interest in pathology and became lecturer in pathology in his old medical school in Dundee. He published more than 80 papers, mainly in haematology, which led to his appointment as reader in haematology. Seconded five times to Ghana, he worked and taught in the medical schools in Accra and Kumasi. He leaves a wife, Jan, who was his great support over the years, and two children. Norman Kinnear Smith

\section{Struan Robertson}

Former consultant ophthalmologist Royal Halifax Infirmary (b 1908; q Edinburgh 1932; DOMS), d 14 December 2006.

From humble beginnings, Struan Robertson worked his way to Edinburgh University where he graduated in 1932. After various jobs as a locum general practitioner in the Scottish highlands he became a ship's doctor, sailing from Liverpool. In the war he worked as a hospital casualty officer in Dartford. He moved into ophthalmology as an assistant at the Royal Halifax Infirmary. Promoted to consultant he worked there until he retired in 1973. His main leisure interest was salmon fishing on the River Ness. He never married.

Peter Davies

\section{Albert Carson Scott}

Former consultant anaesthetist MidUlster Hospital, Belfast (b 1937; q Belfast 1961; MD), d 28 September 2006.

After qualifying, Albert Carson Scott ("Bertie") first gained an MD in

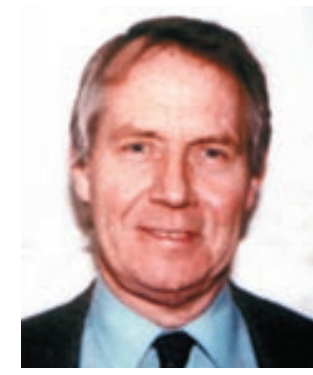

physiology and then trained in anaesthesia. In 1974, he emigrated to Canada to learn paediatric and cardiac anaesthesia at the IWK Children's Hospital, Halifax. In 1982 he returned for family reasons to Northern Ireland and worked in the Mid-Ulster Hospital as a general anaesthetist, until he lost his left eye as a result of cancer in September 2001. He was a good all round sportsman but preferred country pursuits as he grew older. He leaves a wife, Jennifer. Jennifer Scott

\section{Nigel Ewart Wood}

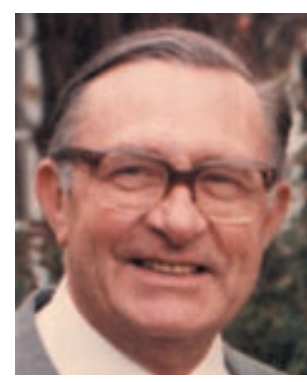

Former general practitioner Blackhill, Consett (b 1920; q Durham 1944; DRCOG, MRCGP), d 4 December 2006.

Nigel Ewart Wood excelled at both rugby and cricket, representing Northumberland at cricket. After qualifying, he served in India with the Royal Army Medical Corps until 1947. In 1948 he set up a medical practice in Blackhill, where he remained in practice until retirement. He was interested in alternative medicine and during the 1960s began using homoeopathy and hypnosis with excellent results. He was also secretary of the BMA's Consett division during this period. Predeceased by his wife, Sylvia, in 2005 , he leaves two sons and five grandchildren. Julian Wood, Gordon Wood 